\title{
LINTASAN SEJARAH PEMERINTAHAN KABUPATEN SERANG ABAD XVI - XX
}

\author{
Oleh Euis Thresnawaty \\ Balai Pelestarian Sejarah dan Nilai Tradisional Bandung \\ Jln. Cinambo No. 136 Ujungberung Bandung \\ Email: bpsntbandung@ymail.com
}

\begin{abstract}
Abstrak
Sejarah pemerintahan daerah Serang mencakup waktu sangat panjang, karena berawal dari pembentukan Kesultanan Banten abad ke-16. Berarti pemerintahan di daerah tersebut berlangsung pada zaman Kompeni, Hindia Belanda, Pendudukan Jepang, dan zaman kemerdekaan.

Dalam perjalanan sejarahnya, Kesultanan Banten mengalami dinamika akibat gejolak situasi politik pada zaman penjajahan, bahkan kesultanan itu akhirnya dihapuskan. Zaman Hindia Belanda dan Pendudukan Jepang, Serang menjadi ibukota Keresidenan Banten dan Kabupaten Serang. Kedudukan Serang yang disebut terakhir berlangsung sampai sekarang. Mulai akhir tahun 2000, Serang kembali memiliki kedudukan penting sebagai ibukota kabupaten merangkap ibukota Provinsi Banten sejak tanggal 4 Oktober 2000.

Dalam perjalanan sejarahnya, banyak peristiwa penting terjadi di daerah Serang yang penting dipetik maknanya. Atas dasar itulah tulisan ini dibuat.
\end{abstract}

Kata Kunci: Sejarah Serang, pemerintahan.

History of goverment of area Serang include;covers very time length, because having beginning of from forming of Sultanate Banten century XVI. Means goverment in the area takes place at period Kompeni, Hindia Belanda, Japan Occupying, and independence.

On the way its the history, Sultanate Banten experiences dynamic as result of distortion of political situation at colonization period, even the sultanate finally is abolished. Dutch Indies period and Occupying Jepang, Serang to become capital of Residence Banten and Sub-province Serang. Position Serang so-called last taken place until now. Starts is year-end 2000, Serang had important position as capital of regency doubles capital of Provinsi Banten commencing from the date of 4 October 2000.

On the way its the history, many important events happened in area Serang which is important is taken the meaning. On the basis of that is this article made.

Keywords: History of Serang, governance.

\section{A. Pendahuluan}

Pada periode pembangunan dewasa ini sangat diperlukan pemahaman mengenai sejarah daerah yang lengkap, terutama bagi para penentu kebijakan. Pemahaman mengenai sejarah masa lalu ini dapat dipergunakan sebagai alternatif 
dalam mencari pemecahan berbagai persoalan pembangunan dewasa ini maupun masa yang akan datang. Pemahaman ini tentu sangat diperlukan agar tidak terjebak dalam pengulangan kesalahan yang telah dilakukan pada masa lampau.

Dengan melihat perubahanperubahan yang terjadi di dalam pemerintahan Kabupaten Serang maka perlu dilakukan kajian terhadap perubahan-perubahan tersebut dari sisi sejarah. Oleh karena itu, dilakukan penelitian mengenai Sejarah Pemerintahan Kabupaten Serang yang difokuskan pada studi perkembangan pemerintahan di Kabupaten Serang Propinsi Banten.

Berdirinya pemerintahan Kabupaten Serang memiliki rentang sejarah yang cukup panjang, dimulai sejak Kabupaten Serang berada di bawah pemerintahan Propinsi Jawa Barat sampai Kabupaten Serang masuk ke dalam wilayah Propinsi Banten.

Penelitian ini memiliki tujuan, yaitu untuk mengantisipasi hilangnya berbagai peristiwa sejarah daerah sebagai bagian dari sejarah nasional dan untuk mengungkap perjalanan sejarah Kabupaten Serang dengan fokus utama pada perkembangan Pemerintahan Kabupaten Serang.

Penelitian sejarah Pemerintahan Kabupaten Serang ini memiliki ruang lingkup aspek spasial meliputi daerah Kabupaten Serang, sedangkan aspek temporal berada pada kurun waktu sejak pembentukan Kabupaten Serang sampai tahun 2000.

Penelitian ini dilakukan dengan menggunakan metode sejarah melalui empat tahapan, yaitu:

1. Heuristik atau proses pencarian dan pengumpulan sumber, pada tahap heuristik ini digunakan tehnik-tehnik sebagai berikut:
a. Studi kepustakaan, dilakukan di berbagai perpustakaan baik di Bandung maupun Serang Banten
b. Kerja lapangan, yaitu langsung menuju ke tempat tujuan.
c. Melakukan wawancara dengan tokoh-tokoh yang berperan atau mengetahui tentang sejarah Kabupaten Serang.

2. Kritik sumber untuk memperoleh kebenaran dan kejernihan data, baik kritik ekstern (tentang wujud sumber) ataupun kritik intern (tentang isi sumber) maupun melakukan perbandingan data yang berasal dari berbagai sumber.

3. Pada tahap interpretasi, data mengalami proses pemberian makna dan penafsiran secara jelas dan lengkap.

4. Historiografi adalah proses terakhir dalam penulisan sejarah yang berupa proses merangkaikan fakta-fakta yang berhasil dihimpun dalam sebuah kisah sejarah.

\section{B. Hasil dan Bahasan}

\section{Kondisi Geografi dan Kependudukan}

Kabupaten Serang merupakan salah satu wilayah yang berada di Propinsi Banten dan sekaligus sebagai ibukota Propinsi Banten. Serang merupakan salah satu dari enam kabupaten/kota di Propinsi Banten, terletak di ujung barat bagian utara Pulau Jawa dan merupakan pintu gerbang utama yang menghubungkan Pulau Sumatra dengan Pulau Jawa, dengan jarak sekitar 70 kilometer dari Jakarta, ibukota Negara Republik Indonesia.

Luas wilayah Kabupaten Serang mencapai 170.341,25 hektar, tersebar menjadi 34 wilayah kecamatan, 353 desa dan 20 kelurahan. Kecamatan-kecamatan yang terdapat di Kabupaten Serang adalah: Kecamatan Serang, Cipocokjaya, Kasemen, Taktakan, Kramatwatu, 
Waringinkurung, Bojonegoro, Puloampel, Ciruas, Walantaka, Kragilan, Pontang, Tirtayasa, Tanara, Cikande, Kibin, Cirenang, Binuang, Petir, Tunjungteja, Curug, Baros, Cikeusal, Pamarayan, Kopo, Jawilan, Ciomas, Pabuaran, Padarincang, Anyer, Mancak, dan Cinangka. Tahun 2007 Serang dimekarkan menjadi dua daerah tingkat II dengan pembentukan Kota Administratif Serang sebagai ibukota Propinsi Banten.

Secara administratif Kabupaten Serang memiliki batas wilayah sebagai berikut:

- Sebelah Utara berbatasan dengan Laut Jawa

- Sebelah Timur berbatasan dengan Kabupaten Tangerang

- Sebelah Selatan berbatasan dengan Kabupaten Pandeglang dan Kabupaten Lebak

- Sebelah Barat berbatasan dengan Selat Sunda

Penduduk Kabupaten Serang berdasarkan data hasil sensus menunjukan jumlah yang terus bertambah. Pada tahun 1961 tercatat sebanyak 648.115 jiwa, tahun 1971 sebanyak 766.410 jiwa, meningkat menjadi 968.358 pada tahun 1980 dan 1.244.755 pada tahun 1990. Pada tahun 2000 jumlah penduduk tersebut telah bertambah lagi menjadi 1.786.223. Sedangkan jumlah penduduk tahun 2006 adalah 1.786.223 terdiri dari 917.132 laki-laki dan 869.091 perempuan (BPS Kab Serang, 2007).

Penduduk Kabupaten Serang sebagian besar memeluk agama Islam. Hanya sebagian kecil yang memeluk agama lain seperti Protestan, Katolik, Hindu, dan Budha. Kehidupan beragama antar pemeluk agama yang berbeda berjalan harmonis dan tidak pernah terjadi pertikaian. Kerukunan hidup dan tenggang rasa dalam beragama telah menjadi bagian dari kehidupan masyarakat. Untuk menunjang kehidupan beragama di Kabupaten Serang telah terdapat sarana peribadatan Islam sebanyak 5.719, gereja 7 , pura 1 , dan 2 vihara. Sementara itu penganut agama Islam 1.890.457 orang, Protestan 4.674 orang, Katolik 2.228 orang, Hindu 3.094 orang, dan Budha 536 orang (BPS Kabupaten Serang, 2007).

Masyarakat Kabupaten Serang sebagian besar menggunakan bahasa Jawa Serang dalam berkomunikasi sehari-harinya. Bahasa Jawa Serang merupakan bahasa Jawa dialek Serang yang berbeda dengan bahasa Jawa standar yang ada di Jawa Tengah. Pemakaian bahasa Jawa di masyarakat Serang erat kaitannya dengan latar belakang historis penyebaran agama Islam oleh para wali yang masuk melalui daerah Banten.

\section{Lambang Daerah}

Lambang Daerah Kabupaten Serang berbentuk perisai dan pita berwarna kuning emas dengan kedua ujungnya dilipat ke bawah, terletak dibagian bawah perisai. Pada bagian perisai terdapat:

a. Garis atas dengan 17 lengkungan, garis bawah 8 lengkungan diantara buah cengkeh sedangkan di bawahnya terdapat empat untai daun dan 5 akar beringin. Hal ini menggambarkan hari Proklamasi RI 17 Agustus 1945.

b. 6 buah cengkeh berwarna merah dan putih yang mencerminkan Rukun Iman, ketakwaan kepada Tuhan Yang Maha Esa sedangkan buah cengkeh melambangkan kemakmuran, hasil pertanian dan perdagangan serta kejayaan daerah dan masyarakat. Warna putih mempunyai arti kesucian. 
c. Menara Mesjid Agung Banten berwarna putih, melambangkan syiar agama dan pusat kegiatan kebudayaan serta pemerintah yang kuat, bersih dan berwibawa.

d. Benteng Keraton Surosowan yang didalamnya terdapat dua puluh enam (26) kotak dan berpuncak 10 kotak serta celah-celah kotak yang berjumlah 8 ini melambangkan hari jadi Kabupaten Serang, yaitu tanggal 8 Oktober 1526. berwarna merah bata yang berarti semangat abadi.

e. Pohon beringin, melambangkan persatuan yang kokoh dan kuat. Berwarna hijau yang berarti kesuburan, kesegaran, dan kesehatan.

f. Dua buah sungai, yang melambangkan bahwa di Kabupaten Serang terdapat dua aliran sungai, yaitu Cibanten dan Ciujung. Warna biru laut mempunyai arti kejernihan suasana dan keaslian watak.

g. Dua buah laut, melambangkan bahwa Kabupaten Serang diapit oleh Laut Jawa dan Selat Sunda. Berwarna biru laut. Pada bagian yang berbentuk pita terdapat tulisan yang berbunyi "Sepi ing pamrih rame ing gawe". Semboyan merupakan himbauan agar masyarakat mengutamakan kerja keras untuk mencapai kemakmuran dan keadilan, tidak mengutamakan kepentingan pribadi, tanpa mengharapkan pujian, penghargaan serta imbalan, berjuang dengan ikhlas. Warna kuning emas berarti keagungan orang-orang mengamalkan motto yang terukir didalamnya.

\section{Sejarah Pemerintahan Kabupaten Serang}

\section{a. Masa Kesultanan Banten}

Menguraikan sejarah pemerintahan di Kabupaten Serang tidak akan terlepas dari sejarah Banten, karena Serang merupakan bagian dari wilayah Kesultanan Banten yang berdiri pada abad XVI. Di daerah Banten, tepatnya di Pulau Panaitan, pernah berdiri kerajaan tertua di Jawa Barat, yaitu Kerajaan Salakanagara (Negeri Perak) dengan pusatnya di Kota Rajatapura yang terletak di pesisir Pandeglang. Selain itu Banten merupakan salah satu pusat penyebaran agama Islam yang berpengaruh besar dalam pengislaman di daerah Jawa Barat, Jakarta (Sunda Kelapa), Lampung, Sumatra Selatan, dan beberapa daerah lain di sekelilingnya.

Dalam bukunya "The Suma Oriental of Pires", Armando Cortesao memaparkan bahwa nama Banten pertama kali muncul dalam laporan perjalanan Tome Pires seorang Portugis yang menjabat sebagai inspektur pajak di Malaka yang ikut dalam ekspedisi ke Jawa pada tahun 1513. Disebutkan bahwa Banten adalah sebuah kota pelabuhan yang ramai dan berada di kawasan Kerajaan Sunda. Kesaksian Tome Pires ini dapat dijadikan petunjuk bahwa Bandar Banten sudah berperan sebelum berdirinya Kesultanan Banten pada tahun 1526, atau pada masa Kerajaan Sunda. Bisa diduga bahwa Banten telah berdiri sekurang- kurangnya pada pertengahan abad kesepuluh atau bahkan abad ke-7.

Pada awalnya masyarakat Banten adalah penganut Hindu-Budha, dan sampai awal abad XVI termasuk daerah kekuasaan Kerajaan Sunda. Pada saat itu Kerajaan Sunda yang dikenal dengan sebutan Pajajaran merupakan kerajaan besar dengan daerah kekuasaan yang meliputi seluruh Banten, Kalapa (Jakarta), Bogor, sampai Cirebon, ditambah pula dengan Tegal dan Banyumas sampai batas Kali Pamali (Cipamali) dan Kali Serayu (Ekadjati,1983: 19). Pelabuhan Banten 
dan Sunda merupakan pelabuhan besar dan ramai yang banyak dikunjungi pedagang dari luar negeri.

Pada awal abad XVI, yang berkuasa di Banten adalah Prabu Pucuk Umum atau disebut juga Ratu Ajar Domas. Pusat pemerintahannya adalah Kadipaten yang terletak di Banten Girang. Sedangkan Banten Lama atau Banten Ilir hanya berfungsi sebagai pelabuhan saja. Untuk menghubungkan antara Banten Girang dengan Pelabuhan Banten dipakai jalur sungai Kali Banten yang pada waktu itu masih dapat dilayari (Ayatrohaedi, 1979:37), disamping masih ada jalan darat yang melalui Kalapadua (Djajadiningrat,1983:124).

Banten yang berada di jalur perdagangan internasional, diduga sudah memiliki hubungan dengan dunia luar sejak awal abad Masehi. Kemungkinan pada abad ke-7 Banten sudah menjadi pelabuhan yang dikunjungi para saudagar dari luar. Ketika Islam dibawa oleh para pedagang Arab ke timur kemungkinan Banten telah menjadi sasaran dakwah Islam. Menurut berita Tome Pires, pada tahun 1513 di Cimanuk sudah dijumpai orang-orang Islam. Setidaknya pada akhir abad ke-15, Islam sudah mulai diperkenalkan di pelabuhan milik kerajaan Hindu Sunda. Ketika Sunan Ampel Denta pertamakali datang ke Banten, ia mendapati orang Islam di Banten, meskipun penguasanya masih beragama Hindu (Michrob dan Chudori:1993:5051).

Pada tahun 1525 Hasanuddin berhasil mengalahkan Prabu Pucuk Umum di Banten Girang dibantu oleh pasukan gabungan Cirebon dan Demak. Selanjutnya atas kesepakatan Demak dan Cirebon diangkatlah Pangeran Hasanuddin menjadi Adipati Banten dengan pusat pemerintahan di Banten Girang. Berdasarkan petunjuk dari Syarif Hidayatullah, Pangeran Hasanuddin memindahkan pusat pemerintahan Banten yang semula berada di pedalaman Banten Girang, sekitar 13 kilometer dari Serang ke dekat Pelabuhan Banten. Hal ini terjadi pada tanggal 1 Muharam tahun 933 Hijriah bertepatan dengan tanggal 8 Oktober 1526. Pada saat pemindahan pusat pemerintahan Banten ke pesisir, Syarif Hidayatullah yang menentukan posisi istana, benteng, pasar, dan alunalun yang harus di bangun di dekat Kuala Sungai Banten yang kemudian dinamakan Surosowan dan menjadi ibukota Kesultanan Banten. Surosowan dipilih sebagai ibukota Kesultanan Banten berdasarkan pertimbangan antara lain karena Surosowan lebih mudah dikembangkan sebagai Bandar pusat perdagangan.

Oleh karena Banten semakin besar dan maju, pada tahun 1552 Masehi, Banten yang semula hanya sebuah kadipaten diubah menjadi negara bagian Demak dengan dinobatkannya Pangeran Hasanuddin sebagai Sultan di Kesulanan Banten dengan gelar Maulana Hasanuddin Panembahan Surosowan (Lubis, 2003:28).

Pada masa pemerintahan Hasanuddin (1552-1570) Banten memperluas wilayah kekuasaannya ke Jayakarta, Karawang, Lampung dan daerah sekitarnya. Langkah pertama Pangeran Hasanuddin sebagai penguasa Banten ialah mendirikan komplek keraton Surosowan yang disebut juga Gedong Kedaton Pakuwon dan mesjid. Mesjid pertama yang didirikannya terletak di Kampung Pecinan sekarang. Pangeran Hasanuddin atau Maulana Hasanuddin bisa dikatakan sebagai orang pertama yang menyusun kekuatan dan kekuasaan Banten sebagai negara yang berdiri sendiri.

Pada tahun 1568 Pangeran Hasanuddin mampu memanfaatkan situasi kemelut yang terjadi di 
Kesultanan Demak untuk melepaskan diri dari pengawasan Demak. Banten menjadi negara merdeka, menjadi kesultanan dengan Sultan Hasanuddin sebagai Sultan pertamanya. Daerah kekuasaannya meliputi seluruh Banten, Jayakarta, Lampung, Bengkulu dan daerah-daerah lainnya di Sumatra bagian selatan. Maulana Hasanuddin memerintah Banten sekitar 18 tahun, ia meninggal pada tahun 1570 Masehi, dimakamkan disamping Masjid Agung Banten. Setelah Maulana Hasanuddin wafat, rakyat Banten menyebutnya Pangeran Surosowan, Penembahan Sedakingkin, yang artinya rindu akan kebijaksanaannya.

Sepeninggal Maulana Hasanuddin sebagai penggantinya adalah Maulana Yusuf, putra pertamanya yang memerintah tahun 1570-1580. Selan-jutnya silih berganti hingga Sultan Banten ke-5. lebih dikenal dengan nama Sultan Ageng Tirtayasa (1651-1672), seorang ahli strategi perang yang dapat diandalkan.

Ia ditangkap pada tanggal 14 Maret 1683, akibat penghianatan putranya sendiri, Sultan Haji yang bekerja sama dengan Belanda. Sultan Ageng Tirtayasa dipenjarakan di Batavia sampai ia meninggal tahun 1692. Atas permintaan keluarganya, khususnya cucunya yaitu Sultan Abdul Al Mahasin Zainul Abidin, jenasah Sultan Ageng Tirtayasa di pulangkan ke Banten dan di makamkan di Kompleks Mesjid Agung Banten (Ekadjati, 1995:101-102; Ensiklopedi Sunda, 2000: 661).

Kedudukan para Sultan yang kemudian silih berganti menduduki tahta selanjutnya tidak lebih dari vassal VOC yang bertindak sebagi Lord sampai berakhirnya kekuasaan VOC pada tahun 1799

Kesultanan Banten dalam struktur pemerintahannya mempunyai hak prerogatif, baik dalam urusan politik maupun agama. Sultan merupakan pemegang kekuasaan tertinggi diikuti oleh sejumlah pejabat kerajaan yang diserahi tugas-tugas tertentu. Para pejabat yang langsung di bawah sultan adalah para pangeran, anggota keluarga sultan, dan anggota-anggota kaum bangsawan lainnya. Mereka memiliki tugas masingmasing, ada yang bertugas mengawasi pasukan pengawal keraton dan budakbudak atau tugas lainnya. Yang tergolong anggota keturunan sultan biasanya tidak dilibatkan ke dalam organisasi administratif. Kekuasaan administratif diserahkan kepada anggota-anggota lapisan atas birokrasi. Yang mengepalai birokrasi pusat adalah Patih yang dibantu oleh dua Kliwon yang biasanya juga disebut patih. Pengadilan keagamaan dipegang oleh seorang ahli agama, disebut fakin.

Pejabat-pejabat tingkat teratas memiliki bawahan yang disebut Ponggawa. Para ponggawa ini memiliki tugas untuk mengatur administrasi dan pengawasan atas penanaman lada produksi, dan perdagangannya Kemudian para Syahbandar yang diberi tugas mengatur administrasi dan pengawasan atas perdagangan luar negeri di kota-kota pelabuhan (Pemda Jabar, 1993: 198). Sejajar dengan pejabat di kota-kota pelabuhan adalah kepala daerah yang mengepalai pemerintahan suatu daerah, yaitu yang berkedudukan di Lebak, Caringin, Pontang, dan Jasinga. Selanjutnya adalah sederetan Ponggawa, Ngabei, Kliwon, dan Paliwara yang bertugas mengawasi gudang-gudang dan urusan rumah tangga keraton atau pejabat-pejabat penghubung (Michrob, 1988: 98).

Penggantian tahta kerajaan yang berlaku di Kesultanan Banten adalah bersifat turun-temurun. Pada dasarnya seorang sultan memegang pemerintahan sampai meninggal. Sebagai pengganti 
sultan yang meninggal adalah putra lakilaki tertua raja yang lahir dari istri permaisuri. Namun apabila hal tersebut tidak memungkinkan maka dapat dipilih putra laki-laki yang lain atau kakak/ adik sultan atau cucu sultan. Apabila putra mahkota belum dewasa, maka pemerintahan untuk sementara dapat dipegang oleh seorang wakilnya, biasanya Mangkubumi.

Kedudukan sultan dalam pemerintahan kerajaan sangat sentral, karena sultan adalah penguasa tertinggi. Oleh karena itu apa yang ditetapkan oleh sultan harus dipatuhi oleh rakyat. Melakukan perbuatan yang bertentangan dengan keputusan sultan akan berakibat buruk atau menerima hukuman. Sultan bukanlah orang sembarangan, mereka yang memerintah dikesultanan Banten adalah keturunan dari Sunan Gunung Jati, pendiri Kesultanan Cirebon.

\section{b. Masa Hindia Belanda}

Gubernur Jenderal H.W. Daendels adalah orang pertama yang memperkenalkan sistem pemerintahan Barat yang modern kepada masyarakat Indonesia. Dalam menjalankan tugasnya di Indonesia, ia sangat memperhatikan urusan pemerintahan dan administrasi negara. Dalam hal ini, Daendels menjalankan pemerintahan yang bersifat sentralistis. Segala kekuasaan dan keputusan berada pada dirinya. Semua urusan pemerintahan, baik pemerintah pusat maupun daerah diatur dari pusat di Batavia. Pejabat-pejabat di daerah hanya menerima dan menjalankan instruksi dari Gubernur Jenderal.

Dalam sistem pemerintahannya Daendels memperkenalkan jabatan prefect, yaitu pejabat Eropa/ Belanda setingkat residen yang menguasai wilayah administratif yang disebut prefectur. Prefect merupakan wakil pemerintah kolonial di daerah yang dikuasainya dan bertanggung jawab langsung kepada gubernur jenderal. Istilah prefect kemudian diubah menjadi landdrost, dan prefectur menjadi landdrostambt.

Daendels menyatakan bahwa semua pejabat, baik pejabat Eropa maupun pribumi adalah pegawai Pemerintah Hindia Belanda. Dengan kata lain, ia memodifikasi kedudukan bupati dari penguasa daerah (tradisional) menjadi aparat pemerintah kolonial yang berada di bawah pengawasan prefect. Sistem pergantian bupati secara turuntemurun tidak diakui, kemudian diganti dengan sistem penunjukkan (Syafrudin, 1993 : 263).

Berdasarkan Regeringsreglement (RR) 1854, pemerintahan di Hindia Belanda tetap bersifat sentralistis, kecuali pemerintahan desa yang dibiarkan otonom berdasarkan adat setempat. Akan tetapi pada pemerintahan yang sentralistis itu dijalankan pula azas dekonsentrasi, yaitu sejumlah tugas pemerintahan dilimpahkan oleh pemerintah pusat yaitu gubernur jenderal kepada pejabat-pejabat pusat yang lebih rendah tingkatannya secara hierarkis. Pejabat-pejabat itu berkedudukan di daerah-daerah dan mereka menjalankan tugasnya terbatas pada lingkungan wilayah jabatan tertentu yang disebut daerah administratif atau pemerintahan lokal administratif (Syafrudin, 1993: 271). Karena pemerintahan dijalankan oleh pangrehpraja, maka pemerintahan itu dikenal dengan sebutan "Pemerintahan Pangrehpraja" (Lubis, 2003: 91).

Dalam sistem pemerintahan kolonial ini meskipun menerapkan sistem pemerintahan modern dan berusaha mengurangi kekuasaan bupati, tetapi pemerintahan tradisional tetap berlangsung tanpa mengalami perubahan sistem pemerintahan. Bupati tetap dibantu oleh 
pejabat struktural dan pejabat fungsional. Pejabat struktural terdiri atas patih, wedana, (kepala distrik/ hoofddistrict), asisten wedana (hoofdonderdistrict), dan lurah (kepala desa). Pejabat fungsional terdiri atas jaksa kepala (hoofdjaksa), penghulu kepala (hoofdpenghulu), kanduruan (kepala/ mantri besar paseban), kumitir kepala (hoofdcommitteer), ondercollecteur (pengumpul pajak, demang, ngabei, kaliwon, panglaku, lengser (kabayan), sejumlah mantri, dan lain-lain (Lubis, 2003: 91).

Tahun 1862 terjadi perubahan dalam pemerintahan tradisional sebagai akibat pemerintahan kolonial memperkenalkan sistem afdeeling dalam pembagian wilayah kabupaten. Tiap kabupaten yang memiliki wilayah cukup luas rata-rata dibagi menjadi dua afdeeling. Secara politis, perubahan itu dimaksudkan oleh pemerintah kolonial untuk mengurangi kekuasaan bupati, karena pemerintahan sehari-hari di wilayah afdeeling dilakukan oleh asisten residen (hoofd van plaatslijke bestuur) dengan didampingi oleh patih afdeeling yang disebut "zelfstandige patih".

Akhir abad ke-19 wilayah Jawa Barat dibagi dalam lima karesidenan. Tiap karesidenan terdiri atas sejumlah afdeeling dan kabupaten. Kelima karesidenan itu adalah:

1. Karesidenan Batavia terdiri atas tiga afdeeling, yaitu Meester Cornelis (Jatinegara), Tangerang, dan Buitenzorg (Bogor).

2. Karesidenan Karawang terdiri atas tiga afdeeling, yaitu Tanah-tanah Negara, Pamanukan dan Ciasem, dan Tegalwaru.

3. Karesidenan Banten terdiri atas empat afdeeling, yaitu Anyer, Pandeglang, Caringin, dan Lebak.

4. Karesidenan Priangan terdiri atas sembilan afdeeling, yaitu: Bandung,
Cicalengka, Cianjur, Sukabumi, Sumedang, Limbangan, Tasikmalaya, dan Sukapura Kolot.

5. Karesidenan Cirebon terdiri atas empat afdeeling, yaitu Indramayu, Majalengka, Kuningan, dan Galuh.

Di antara 5 daerah tersebut, pada abad ke-19 perubahan politik dan pemerintahan terutama terjadi di tiga daerah yaitu Karesidenan Banten, Karesidenan Priangan, dan Karesidenan Cirebon, karena daerah Karawang dan Batavia khususnya, telah berada di bawah kekuasaan kolonial sejak abad ke17.

\section{c. Masa Pendudukan Jepang}

Setelah tentara Jepang berkuasa di Jawa, Panglima Tentara ke-16 mengeluarkan Undang-Undang No. 1 tahun 1942. Undang-undang tersebut merupakan induk peraturan tentang tata negara selama pemerintahan sementara militer Jepang. Undang-undang ini berisi antara lain:

Pasal 1 : Balatentara Nippon melangsungkan pemerintahan militer sementara waktu itu di daerah yang telah ditempati agar supaya mendatangkan keamanan yang sentosa dengan segera.

Pasal 2 : Pembesar Balatentara Nippon memegang kekuasaan yang dahulu berada di tangan Gubernur Jenderal.

Pasal 3 : Semua badan pemerintah, kekuasaan hukum, dan undang-undang dari pemerintah yang dahulu tetap diakui untuk sementara waktu, asal tidak bertentangan dengan Pemerintah Militer.

Pasal 4 : Bahwa Balatentara Jepang akan menghormati kedudukan dan kekuasaan pegawai-pegawai yang setia kepada Jepang. 
Apabila melihat isi dari undangundang tersebut tergambar jelas bahwa jabatan gubernur jenderal pada masa Pemerintahan Hindia Belanda dihapuskan dan segala kekuasaan yang berada di tangan gubernur jenderal sekarang dipegang oleh pembesar tentara Jepang. Aparat pemerintahan bangsa Indonesia tetap diteruskan, sejak dari jabatan bupati ke bawah.

Susunan pemerintahan militer Jepang di Jawa terdiri atas Gunsyireikan atau Saikosyikikan sebagai pimpinan tertinggi pemerintahan yang dipegang oleh Panglima Tentara ke-16. Tetapi operasional pemerintahan sehari-hari dilaksanakan oleh Kepala Stafnya yang disebut Gunseikan. Staf Gunseikan disebut Gunseikanbu. Gunsyireikan menetapkan peraturan-peraturan yang dinamakan Osamu Seirei, sedangkan peraturan yang dikeluarkan oleh Gunseikan disebut Osamu Kanrei. Peraturan-peraturan itu diumumkan dalam Kan Po (Berita Pemerintah), penerbitan resmi yang dikeluarkan oleh Gunseikanbu. Panglima Tentara ke-16 di Pulau Jawa yang pertama adalah Letnan Jenderal Imamura Hitosyi dengan Kepala Stafnya Mayor Jenderal Seizaburo Okazaki. Mereka diserahi tugas untuk membentuk pemerintahan militer sementara di Jawa. Yang diangkat menjadi kepala Gunseibu (gubernur) di wilayah Jawa Barat adalah Kolonel Matsui, bekas komandan pasukan yang merebut Bandung dengan wakilnya $\mathrm{R}$. Pandu Suradiningrat dan Atik Suardi sebagai pembantu wakil Gubernur.

Pada tanggal 29 April 1942 diangkat empat orang putra Jawa Barat menjadi residen di wilayah Jawa Barat, yaitu :

1. R.A.A. Hilman Jayadiningrat, sebagai Residen Banten yang berkedudukan di Serang.
2. R.A.A. Suryajayanagara, sebagai Residen Bogor yang berkedudukan di Bogor.

3. R.A.A. Wiranatakusumah, diangkat sebagai Residen Priangan yang berkedudukan di Bandung. Dalam pelaksanaannya ia tidak sampai menjalankan kekuasaan sebagai residen, melainkan hanya sebagai Penasehat Residen Priangan Kolonel Matsui.

4. Pangeran Aria Suriadi, diangkat sebagai Residen Cirebon yang berkedudukan di Cirebon.

Pemerintahan Sementara Militer Jepang berakhir pada bulan Agustus 1942. Pada bulan tersebut dikeluarkan Undang-undang No. 27 tentang aturan pemerintahan daerah dan Undang-undang No. 28 tentang aturan pemerintahan Syu dan Tokubetsu Syi. Kedua Undangundang tersebut merupakan pelaksanaan reorganisasi struktur pemerintahan yang semula sifatnya sementara, yang mengakhiri eksistensi Gunseibu.

Selanjutnya dilakukan reorganisasi pemerintahan setelah datang tenagatenaga ahli pemerintahan sipil Jepang di Pulau Jawa. Tenaga-tenaga ahli ini mulai ditempatkan pada badan-badan pemerintahan untuk melaksanakan reorganisasi. Dengan perubahan pemerintahan itu dimaksudkan oleh penguasa militer Jepang untuk menjadikan Pulau Jawa yang tanahnya subur sebagai sumber perbekalan perang di daerah selatan.

Kedudukan tinggi dalam struktur pemerintahan, yaitu di atas jabatan bupati, yang semula diserahkan kepada orang Indonesia, diambil alih oleh orang Jepang. Pribumi hanya menduduki jabatan bupati ke bawah. Adapun isi Undang-undang No. 27 tahun 1942 adalah: 
Pasal 1 : Tanah Jawa dan Madura, kecuali Kooti (Vorstenlanden, daerah kesultanan), terbagi atas Syu, Syiken, Gun, Son, dan Ku.

Pasal 2 : Daerah Syu sama dengan residen dahulu.

Pasal 3 : Daerah Syu dibagi atas Syi dan Ken. Daerah Ken terbagi atas Gun, dan daerah Gun terbagi atas Son, dan $K u$ sama dengan distrik, onderdistrict, dan desa.

Pasal 4 : Di dalam Syi, Ken, Gun, Son, dan $K u$, masing-masing diangkat seorang Syityoo, Kentyoo, Guntyoo, Sontyoo, dan Kutyoo. Aturan yang berlaku pada Stadsgemente, regentschap, district, onderdistrict, dan desa tetap berlaku pada Syi, Ken, Gun, Son, dan $K u$.

Pasal 5 : Syi yang ditunjuk Gunseikan dinamai Tokubetsoe Syi.

Walaupun tidak ada perubahan struktural, namun terdapat perbedaan di dalam pelaksanaan pemerintahannya. Luas daerah Syu sama dengan keresidenan dahulu, tetapi fungsi dan kekuasaannya berbeda. Residen dahulu merupakan pejabat daerah sebagai pembantu gubernur. Sedangkan Syu merupakan pemerintahan daerah tertinggi dan bersifat otonom. Syu dikepalai oleh Syucokan yang kedudukannya sama dengan gubernur dulu. Seorang Syucokan memegang kekuasaan tertinggi di daerahnya, karena ia mempunyai kekuasaan legislatif disamping kekuasaan eksekutif (Syafrudin, 1993: 351).

Banten Syu membawahi beberapa Ken (Kabupaten), yaitu Serang, Pandeglang, dan Lebak. Syucokan (Residen) yang pernah mengepalai wilayah Keresidenan Banten ialah :

- Letkol Onokuchi (1942)

- Kolonel Orio (1942-1943)
- Watanabe Hirosyi (1943-1944)

- Banjokyjosji (1944-1945)

\section{d. Masa Kemerdekaan}

Tanggal 19 Agustus 1945, Pemerintah berhasil menyusun 12 kementrian, diantaranya Departemen Dalam Negeri yang dipimpin oleh R.A.A Wiranatakusumah. Pada tanggal itu pula PPKI berhasil membentuk delapan propinsi yang dikepalai seorang Gubernur dan masing-masing propinsi terdiri atas karesidenan-karesidenan yang dipimpin oleh residen. Kedelapan propinsi itu ialah Jawa Barat, Jawa Tengah, Jawa Timur, Sumatra, Borneo, Sulawesi, Maluku, dan Sunda Kecil. Masing-masing dipimpin oleh Gubernur. Sebagai Gubernur Jawa Barat adalah R.Sutarjo Kartohadikusumo.

Berdasarkan amanat pasal 18 UU Dasar 1945 berikut, pasal I dan II Aturan Peralihan UUD RI JO Peraturan Pemerintah no. 2 tahun 1945, dibentuk karesidenan-karesidenan yang masingmasing dikepalai oleh residen. Selanjutnya setiap karesidenan dibagi lagi atas kabupaten-kabupaten dan kotapraja yang diperintah oleh Bupati dan Walikota. Para Pejabat kepala daerah tersebut yaitu residen, bupati, dan walikota pada umumnya ditunjuk/dipilih oleh Komite Nasional Indonesia Daerah (KNID) setempat. Sebagian dari mereka yang ditunjuk adalah orang-orang yang pernah menduduki jabatan yang sama pada masa pemerintahan Militer Jepang. Sebagai realisasi UUD 45 dan PP no 2 tahun 1945 di Jawa Barat kemudian dibentuk lima karesidenan, 18 Kabupaten, dan 5 Kotapraja. Salah satu karesidenan di Provinsi Jawa Barat adalah karesidenan Banten dengan residennya yaitu R.Ng.Tirtasoejatna.

Setiap karesidenan terdiri atas beberapa Kabupaten dan Kotapraja. Karesidenan Banten terdiri atas tiga 
Kabupaten yaitu Kabupaten Serang, Lebak, dan pandeglang. Para bupati yang ditunjuk/diangkat baik oleh pemerintah pusat maupun oleh KNID setempat, diantaranya adalah R.Hilman Jayadiningrat sebagai Bupati Serang; K.H TB. Hasan sebagai Bupati Lebak; dan K.H. TB. Abdul Halim sebagai Bupati Pandeglang (Lubis, 2003: 207208).

Pada dasarnya pembagian wilayah administratif tersebut sama seperti pada masa akhir Hindia Belanda. Demikian pula pembagian pemerintah daerah dari tingkat kabupaten ke bawah tetap seperti keadaan sebelumnya. Walaupun sudah diangkat gubernur sebagai penguasa tertinggi di setiap propinsi, namun dalam bulan-bulan pertama setelah proklamasi roda pemerintahan daerah belum berfungsi dengan baik karena kegiatan pemerintahan tergeser oleh kegiatan perjuangan menegakkan kemerdekaan dan mempertahankan kemerdekaan serta mencegah kembalinya kekuasaan kolonial yang lebih bersifat perjuangan fisik bersenjata daripada bersifat politik.

Pada akhir bulan Agustus 1945 diadakan musyawarah para tokoh Banten baik dari golongan pemuda, jawara, wanita, maupun kelompok masyarakat lainnya. Musyawarah diadakan di rumah Dzulkarnaen Surya Kartalegawa di Serang. Dalam musyawarah diputuskan bahwa pengambil alihan kekuasaan diserahkan kepada Dzulkarnaen, urusan perjuangan pemuda diserahkan kepada Ali Amangku, urusan pemerintahan sipil kepada K.H. Tb. Achmad Chatib, dan urusan militer kepada K.H. Syam,un. Sedangkan K.H. Tb. Achmad Chatib pada tanggal 2 September 1945 diangkat oleh pemerintah RI sebagai Residen Banten. K.H. Tb. Achmad Chatib adalah putra seorang ulama terkenal dari Pandeglang yaitu K.H. Tb. Muhammad Waseh, dan menantu dari K.H. Tb.
Asnawi, seorang ulama terkenal dari Caringin.

Sebagai Residen Banten yang dipilih rakyat, K.H. Tb. Acmad Chatib mulai menjalankan tugas dengan menyusun personalia pemerintahan di Karesidenan Banten. Semua pejabat lama tetap duduk dalam jabatan masingmasing. Para bupati yang menjabat waktu itu masing-masing adalah Bupati Serang Raden Tumenggung Aria Hilman Djayadiningrat, Bupati Pandeglang Raden Tumenggung Djoemhara Wiriaatmadja, dan Bupati Lebak Raden Tumenggung Hardiwinangun.

Apabila di telaah lagi, sejak adanya jabatan Regent atau Bupati pada tahun 1826 sampai tahun 2008, telah terjadi 32 kali pergantian Bupati di Kabupaten Serang.

\section{Daftar Regent/ Bupati Kabupaten}

\section{Serang}

1. Pangeran Mudzafar Adi Santika : $\quad$ 1816-1827 (Regent)

2. Agaes Rajak R.A. Djayakusumaningrat: $\quad$ 1828-1840 (Regent)

3. R.T. Mandoera Radja Djajanagara $\quad: \quad$ 1840-1848 (Regent)

4. R. Toemenggoeng Basudin : $\quad$ 1849-1870 Tjandranagara (Regent)

5. R.T. Pandji Gandakoesaemo : $\quad$ 1870-1880 (Tb. Hanafi) (Regent)

G. R. Toemenggaeng Sutadiningrati : $\quad 1888-1893$ Murawan (Regent)

7. R. Toemenggaeng Bagus Djaja $\quad$ : $1893-1898$ (Regent)

8. R. Ariadjajaatmadja (Regent) : $1898-1901$

G. R.A. Achmad Djajadiningrat (Regent) : $\quad$ ISOI-1904

10. R. Toemenggaeng Prawirokoesoemo : 1904-1931 (Limbangan)

II. R.A.A Abas Saerianataatmadja : 1931 -1935 (Priangan)

12. R.A.A. Hilman Djajadiningrat (Banten) : $1935-1945$

13. Kolonel K.H. Syam'um (Bupati) : 1945-1949

14. Mas Parmadidjaja (Bupati) : $1949-1950$

15. Entol Dyong Tarnaya (Bupati) : 1950-1955

16. Mas Adjenam Bin Mas Basa (Bupati) ： $1955-1957$ 
17. M. Sirian Sutawidjaja (Bupati)

18. R. Bidin Suria Gunawan (Pj. Bupati)

19. M. H. Gogu Rafiudin Sandjadirdja (Bupati)

20. Letnan Kolonel Tb. Suwandi (Bupati)

21. H.S. Ronggowaluyo (pj. Bupati)

22. Kolonel H. Tb. Saparudin (Bupati)

23. Drs. Kartiwa Suryasaputra (Bupati)

24. Letnan Kolonel Atmawidjaja (Bupati)

25. H.Tjakra Sumarna (Bupati)

26. H.M.A. Sampurna (Bupati)

27. Kolonel H. Sukron Roshadi (Bupati)

28. Kolonel Inf. Salichin Dachlan (Bupati) :

29. R. Nuriana/Gubernur Jawa Barat (Pj. Bupati)

30. Drs. H. Rosadi Natawisastra (pj. Bupati)

31. Drs. H. Bunyamin, MM, MBA (Bupati) :

32. Drs. H. Rivai, M.Si (Pj. Bupati)

33. Drs. H. A. Taufik Nuriman, MM, MBA (Bupati)

\section{Daftar Sultan Banten}

1. Maulana Hasanuddin Panembahan Surosowan

2. Maulana Yusuf Panembaha Pakalangan

3. Maulana Muhammad Pangeran Ratu Banten

4. Sultan Abdul Mafakir Mahmud

5. Sultan Abdul Maali Achmad Kenari

6. Sultan Ageng Tirtayasa Abdul Fath

7. Sultan Haji Abu Hasri Abdul Kahar

8. Sultan Abdul Fadhal

马. Sultan Abdul Mahasin Jainul Abidin

10. Sultan Muh. Syifai Jainul Arifin

II. Sutan Syarifuddin Ratu Wakil

12. Sultan Muh. Wasi Jainul Alimin

13. Sultan Muh. Arif Zainul Asyikin

14. Sultan Abdul Mafakh Muh. Aliuddin

15. Sultan Muhyidin Zainussalihin

16. Sultan Muh, Ishak Jainul Mutaqin

17. Sultan Pangeran Wakil Natawijaya

18. Sultan Aliudin (Aliudin II)

19. Sultan Pangeran Wakil Suramanggala :

20. Sultan Muhammad Syafiudin

21. Sultan Muhammad Rafiudin
1957-1959

$1959-1960$

$1960-1962$

$1962-1968$

$1968-1974$

1974-1975

1975-1978

1978-1983

$1983-1988$

$1988-1993$

$1993-1998$

1998-1999

1999

1999-2000

2000-2005

2005

2005 -

sekarang

$1552-1570$

1570-1580

1580-1596

1596-1640

$1640-165 \mid$

$1651-1672$

1672-1687

$1687-1690$

$1690-1733$

1733-1750

1750-1752

$1752-1753$

1753-1773

1773-1799

1799-1801

1801-1803

1803

$1803-1808$

$1808-1809$

$1809-1813$

$1813-$

\section{Penutup}

Perjalanan sejarah pemerintahan Kabupaten Serang diwarnai dengan perubahan bentuk pemerintahan, yaitu dari bentuk pemerintah lokal dan kabupaten. Jejak sejarahnya tidak bisa lepas dari perjalanan panjang Banten yang kini telah menjadi Propinsi, memisahkan diri dari Propinsi Jawa Barat sejak 4 Oktober 2000. Perubahan pemerintahan itu telah berlangsung lama sejak abad 18 yaitu sejak masa Kesultanan kemudian masa Kolonial Hindia Belanda, Pendudukan Jepang, hingga masa kemerdekaan. Sebelumnya Banten Girang dipilih sebagai pusat pemerintahnya, tetapi karena letaknya dipedalaman, pusat pemerintahan dipindahkan ke Keraton Surosowan, Serang. Dipilihnya Surosowan atau Serang sebagai pusat pemerintahan Kabupaten Serang, karena lokasi ini sangat strategis bagi komunikasi antara Priangan, Batavia (Jakarta) dan wilayah Pulau Sumatra. Selain itu, Serang merupakan tempat yang nyaman bagi peristirahatan serta memiliki potensi ekonomi yang cukup tinggi karena memiliki pelabuhan besar Merak, serta kekayaan sumber alam, khususnya bidang industri.

Berdasarkan keputusan Gubernur Jenderal Hindia Belanda tanggal 19 September 1870, pemerintah Hindia Belanda mengadakan perubahan struktur pemerintahan, berupa pembentukan beberapa afdeling di Jawa Barat. Afdeling itu antara lain Afdeling Serang yang berada di bawah Residentie Banten Regentchappen, yang dipimpin oleh seorang Asisten Residen.

Dari uraian diatas dapat disimpulkan bahwa pemerintahan di Serang telah mengalami 4 (empat) kali masa peralihan kekuasaan/pemerintahan, yaitu:

1. Pemerintahan Kesultanan Kerajaan

Banten yang berkuasa selama kurang lebih 290 tahun, dimulai 
sejak Sultan Maulana Hasanuddin yaitu tahun 1526 sampai tahun 1816 . Dan ketika berdirinya Keraton Surosowan sebagai pusat pemerintahan yang ditandai dengan penobatan Pangeran Sabakingkin dengan Pangeran Hasanuddin pada tanggal 1 Muharam $933 \mathrm{H} /$ 8Oktober $1526 \mathrm{M}$, kemudian dijadikan landasan penetapan sebagai Hari Jadi Kabupaten Serang.

2. Pemerintahan Hindia Belanda yang berkuasa selama kurang lebih 126 tahun yaitu dari tahun 1816 sampai tahun 1942.

3. Pemerintahan Jepang yang berjalan selama 3,5 tahun yaitu dari tahun 1942 sampai tahun 1945.

4. Pemerintahan Republik Indonesia dimulai sejak Kemerdekaan Republik Indonesia tanggal 17 Agustus 1945 diproklamasikan sampai sekarang.

\section{DAFTAR PUSTAKA}

Ayatrohaedi. 1995.

Banten Sebelum Islam, Dalam

Banten Kota Pelabuhan Jalan Sutra. Jakarta: Depdikbud.

BPS Kabupaten Serang. 2000.

Serang Dalam Angka. Serang: BPS.

BPS Kabupaten Serang. 2007.

Serang Dalam Angka. Serang: BPS.

Djajadiningrat, R. Husein. 1982.

Tinjauan Kritis Sejarah Banten. Jakarta: Djambatan.

Djajadiningrat, P.A.A. 1937.

Kenang-kenangan Pangeran Aria

Achmad Djajadiningrat. Batavia:

Kolff-Buning- Bale Pustaka.

Ekadjati, Edi S. et al. 1978/1979.

Sejarah Kebangkitan Nasional Daerah Jawa Barat. Bandung: Depdikbud Proyek PPKD Jabar.
1982.

Sejarah Revolusi Kemerdekaan

Daerah Jawa Barat. Jakarta: Depdikbud.

Ekadjati, Edi S. 1995.

"Kesultanan Banten dan Hubungannya Dengan Wilayah Luar" dalam Banten Kota Pelabuhan Jalan Sutra. Jakarta: Depdikbud.

Hakim, Lukman. 2006.

Banten Dalam Perjalanan

Jurnalisti. Banten Heritage.

Ismail, Muhammad. 1983.

Petunjuk Jalan dan Keterangan Bekas Kerajaan Kesultanan Banten. Serang: Saudara.

Lubis, Nina H. et al. 2000.

Sejarah Kota-kota Lama Jawa Barat. Bandung: Alqaprint.

Lubis, Nina H. 2003.

Banten Dalam Pergumulan Sejarah. Jakarta: LP3ES.

2003.

Sejarah Tatar Sunda. Jilid I dan II Bandung: Satya Historika.

Michrob, Halwany. 1990.

Catatan Masa Lalu Banten. Serang: Penerbit Saudara.

Michrob, Halwany. 1993.

Sejarah Perkembangan Arsitektur Kota Islam Banten. Jakarta: Yayasan Baluwarti.

Roesjan, Tb. 1954.

Sedjarah Banten, Djakarta: Penerbit Arief.

Syafrudin, Ateng, 1993.

Sejarah Pemeritahan di Jawa Barat. Bandung, Pemda Propinsi Jawa Barat. 